\title{
Family Influence in Maltese Listed Companies: The Implications on Corporate Governance
}

\author{
Submitted 5/11/18, 1st revision 17/12/18, accepted 11/2/19
}

\author{
Peter J. Baldacchino ${ }^{1}$, Annette Gauci ${ }^{2}$, Simon Grima ${ }^{3}$
}

\begin{abstract}
:
The Maltese market is and has always been, dominated by Family Businesses (FB) to the extent that such entities are vital to the resilience of our economy.

There tends to be the presupposition that as soon as FBs convert to a public listing, they start implementing rational governance mechanisms, contrasting with the "non-rational behaviour" which is normally associated with the dynamics of running an FB.

With this study the authors focus on equity-listed Maltese companies on the Malta Stock Exchange (MSE) and aim to build an understanding on the current situation of such entities' GC structures to possibly conclude on whether Maltese LFBs are taking the initiative to apply appropriate governance measures which meet their strategic needs, even though there are no obligatory regulations or recommendations on the matter.
\end{abstract}

Moreover, they will shed light on (i) the characteristics of LFBs; (ii) the family governance structures ('FGS') in such companies including the role of family institutions as well as the family influence on executive appointments and top positions; and (iii) recommend regulatory and other improvements.

Authors carried out semi-structured with 18 participants in charge of corporate governance in Maltese listed companies (MLCs) and conclude that Maltese LFBs do not as yet acknowledge the significance of their distinctive features and the implications of such features on their CG structures. As a result, the application of specific structures related to $F B s$, in particular, the family constitution and the family institutions are as yet not to be found.

Keywords: Family Businesses, Corporate Governance, Rational Behaviour, regulations.

\footnotetext{
${ }^{1}$ University of Malta, Head Accounts Department, Faculty of Economics, Management and Accountancy, corresponding author, peter.j.baldacchino@um.edu.mt

${ }^{2}$ University of Malta, Accounts Department, Faculty of Economics, Management and Accountancy, Annette.gauci.13@um.edu.mt

${ }^{3}$ University of Malta, Head Insurance Department, Faculty of Economics, Management and Accountancy, corresponding author, simon.grima@um.edu.mt
} 


\section{Introduction}

The first decade of the 21st century was characterized by several major corporate failures, in particular, Enron, WorldCom and Parmalat. These raised serious doubts on Corporate Governance (CG) applications at the time (Coffee, 2005) since evidence indicated that the main driving force behind such failures was significant deficiencies in these structures (Dibra, 2016). Following these major collapses, the notion of CG regained due importance and various countries initiated specific programs with the aim of developing CG principles (Calder, 2008) on both national and international levels.

The term 'governance' is stemming from the Latin word "gubernare", which means 'to steer' (Dibra, 2016, p.283), implying that CG is more concerned with giving direction. Over the years, the term CG has been given several definitions. The UK Cadbury Report defines CG as "the system by which companies are directed and controlled" (Cadbury, 1992, p.15). This same definition has been adopted by the Maltese Working Group on CG upon formulating the local Code of Principles of Good Corporate Governance ('Code'). The Cadbury Report also specifies that whilst directors are responsible for the company's governance, shareholders shall contribute to governance by appointing directors and auditors and weighing their satisfaction with regards to how the company is being governed (Cadbury, 1992). $\mathrm{CG}$ is mainly concerned with three main elements, being directors, senior management and shareholders, all having particular roles to play.

\section{Defining Family Businesses}

One of the main challenges encountered by the majority of family firm researchers is the absence of an internationally acknowledged definition of the term 'family business' (FB) (Kraiczy, 2013). Despite this, many researchers believe that the classification of FBs should be done on a case-by-case basis (Astrachan, Klein and Smyrnios, 2002). Nevertheless, over the years, various family firm researchers have attempted to develop an appropriate explanation of the term, taking into account different considerations (Kraiczy, 2013). The diverse interpretations of FBs mainly originate from the different degrees of family involvement within the firm.

Due to the lack of a widespread interpretation of the term, the definition adopted in a particular study could have an impact on the understanding of the results. Therefore, family firm researchers shall clearly state what they understand by such a term for the purpose of their research. In their imperative study, Anderson and Reeb (2003) defined FBs on the basis of family equity holdings and family representation within the Board of Directors ('Board'). On the other hand, the European Commission (2009), specifies that listed entities shall meet the definition of family-controlled businesses if the founder or family members own more than $25 \%$ of the entities' share capital. Notwithstanding the fact that no common definition exists, Hnilica and 
Machek (2015) argue that there are three essential elements when defining FBs; family ownership, family management and family Board membership.

This study focuses on equity-listed Maltese companies on the Malta Stock Exchange (MSE). The majority of Maltese listed companies ('MLCs') do not disclose information on the composition of their management team and therefore, the researcher was not able to identify family representation at the management level. For this reason, the distinction between listed family businesses (LFBs) and listed non-family businesses (LNFBs), has been made on the basis of shareholding and Board membership. For the purpose of the current study, both family-controlled businesses - having more than $25 \%$ of share capital held by the founding family and two or more family directors - and family-influenced businesses - having less than $25 \%$ of share capital held by the founding family and two or more family directors were grouped under the term 'LFBs'.

\section{The Need for the Study}

The Maltese market is and has always been, dominated by FBs to the extent that such entities are vital to the resilience of our economy. The fact that these firms are characterized by a mixture of family and business welfares suggests that the CG requirements of large FBs, which may also be publicly traded, are different than those of non-family businesses ('NFBs') (García-Ramos, Díaz-Díaz and GarcíaOlalla, 2017). Still, the ideologies behind good governance are widely treated as generic principles (Filatotchev, Jackson and Nakajima, 2013) with no concern for the setting within which such principles are to be adopted.

There tends to be the presupposition that as soon as FBs convert to a public listing, they start implementing rational governance mechanisms, contrasting with the "nonrational behaviour" which is normally associated with the dynamics of running an FB (García-Ramos, Díaz-Díaz and García-Olalla, 2017, p.121). As a matter of fact, rather than having good $\mathrm{CG}$ recommendations which differentiate between LFBs and LNFBs, family executives are continuously advised to conduct themselves as outside professionals (ibid.) without recommending any practices of how this can be achieved.

The main recommendations found in the Code are not mandatory and therefore the extent to which these are being observed is still dubious. Additionally, notwithstanding the fact that FBs are key players in the Maltese economy, the Code fails to provide specific guidance with respect to Maltese LFBs. In light of this, the present study attempts to build an understanding on the current situation of such entities' CG structures to possibly conclude on whether Maltese LFBs are taking the initiative to apply appropriate governance measures which meet their strategic needs, even though there are no obligatory regulations or recommendations on the matter. In this context, this study will attempt to (i) ascertain the characteristics of LFBs; (ii) assess the family governance structures ('FGS') in such companies 
including the role of family institutions as well as the family influence on executive appointments and top positions; and (iii) recommend regulatory and other improvements.

\section{Methodology}

\section{i. $\quad$ The Research tool}

Semi-structured scheduled interviews were considered to be the most adequate research tool for attaining the objectives of this study. One predominant feature of a semi-structured interview is that it enables the researcher to develop an interview schedule, which sufficiently addresses the research questions while allowing the participants to delve deeper by providing their insights on the topics discussed (Galletta, 2013). Moreover, semi-structured interviews enable the researcher to question the reasoning behind the interviewees' responses. Since identical questions are being asked, data collected will be comparable (McIntosh and Morse, 2015). Consequently, semi-structured interviews are presumed to absorb the features of two other widely used research tools, namely structured questionnaires and unstructured interviews.

The pre-established interview questions have been targeted toward companies having their equities listed on the MSE. Although the study focuses on LFBs, respondents from all MLCs have been sought, aiming to gather different viewpoints on the topic. The interview schedule includes a mixture of closed-ended and openended questions. The closed-ended questions were prepared in the form of a Likert scale, and the interviewees have been requested to rate their responses using a scale between ' 0 ' for strongly disagree to ' 4 ' for strongly agree.

\section{ii. $\quad$ The Sample Population}

The researcher seeks the opinion and perspective of certain professionals actively involved in the area of the study. Consequently, a purposive sampling technique has been considered to be the most suitable technique, which will enable the researcher to address the research problem and meet the research objectives (Saunders, Lewis and Thornhill, 2007). After deliberating on the research area and the research questions, it was established that company secretaries of MLCs are the target population for the present study.

A list of equity listings was extracted from the MSE website. In order to determine which MLCs meets the definition of family-controlled or influenced companies adopted by this study, the researcher evaluated published company information. It was concluded that 7 out of 22 MLCs fall within the definition of LFBs as adopted by this study. In total, 18 interviews with representatives from MLCs have been conducted and participated in the interviews. The interviewees represent 20 companies; 19 companies having their equity listed on the MSE as at 31st March 2018 and 1 former MLC which was recently taken over by another MLC. Moreover, 2 interviewees occupy the role of company secretary in multiple MLCs. 


\section{iii. The Analysis}

Quantitative data received from the closed-ended statement/question was inputted into Ms Excel and the mean score value calculated and analysed visually by looking at whether this was closer to the ' 0 ' - Strongly agree, ' 1 '- agree, '2'- neutral, ' 3 'disagree or '4'- strongly disagree value scale. However, this data was not seen in isolation but together with the interviewees' comments following their choice of value on the Likert scale to each statement/question. Such qualitative responses were evaluated by means of summarising the transcripts and interview notes and grouping similar responses (Braun et al., 2006).

\section{iv. Limitations}

Despite the efforts exerted, two MLCs' representatives declined the researcher's invitation for an interview and another two did not respond at all. Moreover, bias in the responses of both LFBreps as well as LNFBreps is inevitable. Several LNFB reps claimed that they have some level of experience with FBs, and others stated that they were never involved with such entities. However, the authors felt that saturation had been reached at 18 interviews since they started to get similar answers (Morse, 1995)

\section{Findings and Discussion: Distinctive Features of LFBs}

\section{a) Is the Performance of LFBs Affected by Family Members' Involvement in Business Affairs?}

In its handbook on family governance, the IFC (2011) stated that having family members occupying different roles in the entity's affairs might cause additional complexities. Research participants explained that such involvement may simultaneously both add value to, as well as intimidate normal business practices. In fact, in line with the views of Miller, Steier and Le Breton-Miller (2016), most interviewees highlighted that business success is within the personal interest of active family members. This is likely to result in an entity-wide mindset of work ethic and enthusiasm, shaping a culture of loyalty and commitment towards the enterprise. This approach may be contrasted with attitudes commonly found within LNFBs, whereby since they do not have a vested interest in the business, directors and other senior recruits may apply a lenient attitude where they are not concerned unless their annual earnings will be affected.

Nevertheless, as interviewees repeatedly emphasized, a family member's personal stake in the business does not give him/her a "God-given right" to occupy any role. For good governance's sake, if a family member wishes to occupy a particular position within the firm, s/he needs to be made to apply for that position like any other non-family member. Then, if such a person is considered to be just as good as the best outside person available, there should be no prejudice against such person owing to family membership. However, in such a situation, many would still prefer to go for an outsider as such person's decisions are generally considered to be more rational. 
b) What Common Characteristics are Associated with LFBs?

When starting an FB, the founders are likely to consider the entity as the vehicle expected to sustain the present and subsequent generations. This approach generates certain attitudes which are quite uncommon in entities not having a family element.

i. Non-Economic Goals: As suggested by Daspit et al. (2017) and also by research participants, FBs are not likely to be solely financially-driven as the family in business normally wishes to infuse family values and principles within business operations. However, if family agendas cease to make business sense, the entity's prospects may be shattered. Other familyoriented motives, such as undergoing well-organised growth procedures and ensuring business continuity, may be beneficial in establishing an adequate business culture. Therefore, measures should be established to promote beneficial motives and eliminate detrimental non-financial ones.

ii. Permanent Posts: Family members occupying senior roles are likely to remain in their position for a longer term - this putting them in a better position to use their tacit knowledge to adequately plan for the future. This is in line with the suggestions put forward by Wallevik (2009) and Athwal (2017). However, as rightly noted by several interviewees, having top positions occupied indefinitely might easily lead to a culture of resistance to change. In most current Maltese LFBs, the Chairman position is occupied by the founder or his successor, and the role has been occupied for quite some time. Although this is understandable, it is necessary to ensure that such persons are surrounded by competent professionals able to provide them with meaningful advice and consultations. Furthermore, if Board members retain their position for prolonged periods, their influence over management might become excessive. Hence, the periodic injection of new blood in the boardroom is more important within an FB scenario.

iii. The illiquidity of Shares: As explained by Mustakallio (2002), the portion of shares retained by the controlling family will determine the extent of the family's influence or control. Consequently, as also pointed out by most interviewees, upon listing, the family is likely to be reluctant to release a significant portion of total equity if control is to be retained. In fact, transfers of Maltese LFBs' shares are generally related to the portion owned by the public and not by the founding family. However, if this attitude persists also in instances when additional capital is required but no alternative sources of finance are available, this may be harmful to business operations and result in growth limitations.

iv. Long-Term Outlook: Moreover, the family unit tends to focus not only on current business success but also on handing over a successful business to succeeding generations. As PWC (2013) explained, FBs tend to apply a longer-term attitude when compared to their non-family counterparts. This is in line with some LFBreps' responses, who stated that their decision-making process would deliberately consider the impact on subsequent generations. This might result in conservative investment strategies, which are less risk- 
based, the consequence of which might be the willingness to occupy a marginal position within the industry, allowing competition to take over.

v. Trust: The extent to which family members involved in business operations trust one another highly depends on the characteristics and values of the family along with the personality and integrity of the principal actors involved. Therefore, it is difficult to generalise in this respect. This is in line with the arguments put forward by Steier (2001) and most interviewees. The implication is that if you have the appropriate family culture generating trustworthy personalities, the likelihood would be of deeper bonds enhancing trust. However, if trust relations among relatives are interrupted, the consequences are likely to be more dangerous and remedying such conflicts might be a more sensitive and prolonged affair.

\section{c) What Are the Resulting Advantages and Disadvantages of Operating an LFB?}

The involvement of family members in business activities may be considered both as a strength and as a weakness. Quite inconsistent with the views of Miller, Steier and Le Breton-Miller (2016), who maintained that family involvement is expected to reap positive results, several interviewees emphasized that this mainly varies with the level of professionalism and technical viability of the individuals involved. If the right family members are appointed, generally they are inclined to be more committed and dedicated to the entity.

Consequently, family members' long-term tenure normally results in an elevated sense of stability. While conforming to the responses of LNFBreps, this premise is also supported by Athwal (2017) and Lee (2006). Moreover, internal and external stakeholders are likely to develop stronger and more meaningful bonds with FBs, particularly if the family has been involved in the business for decades and enjoy a reputable market standing. However, as rightly stated by some interviewees, such bonds tend to be stronger in earlier generations, being weakened later on by the involvement of extended family members.

In any case, the involvement of family members may also have its drawbacks. To begin with, although conflicts are a feature inherent to all business operations, matters seem to be more sensitive when there are family relations involved. As argued by PWC (2012) and some research participants, one such common cause for conflict is the issue of succession. Additionally, instances of blind family appointments and distinctions between family and non-family employees are difficult to do away with. The repercussions of such circumstances on business performance will be subject to the position in question as well as to the size of the firm. Moreover, leniency towards family candidates may also prevent a fair judgment with respect to the persons most fitting for particular roles or promotions. Consequently, as Cadbury (2000) insists, this lack of objectivity is likely to negatively impact outside professionals employed by the company and the future prospects which they perceive. 


\section{The Family Governance Structure}

a) Who is appointed on the Board of LFBs?

When appointing or electing Board members, LFBs are likely to consider a number of features which are not commonly considered by LNFBs. It is indeed "natural" to expect members of the founding family to encourage the appointment of family directors. This may be partly because family shareholders tend to consider such appointments as a means through which they can exert a degree of influence over business dealings. Therefore, caution needs to be taken for objectivity in the selection process not to be impaired.

Furthermore, Cannella, Jones and Withers (2015) and most LNFBreps agree that the unique characteristics associated with FBs render candidates holding previous experience in FB corporate affairs to be a better fit. However, this conflicts with the view held by LFBreps stating that such a feature is not particularly taken into consideration when appointing directors. It may be that specific experience in FBs is more valued in practice than LFBreps themselves declare. When appointing Board members, family relations and bonds are also often considered but it would be imprudent if LFBs appoint family members who are inexperienced, unprofessional and with a bad market reputation. However, although most interviewees indicated that such entities look for a mix of worthwhile attributes when selecting Board members, several LNFBreps held that family relations and bonds are likely to take precedence over other more significant features.

\section{b) How Should LFBs' Boards be Composed?}

The quest for an appropriate balance between family and non-family directors remains an important dilemma which may vary with the characteristics and nature of each particular company. Having a suitable proportion of non-family and independent directors is likely to assist in safeguarding transparency, accountability and confidence in LFBs Boards' performance. In fact, the involvement of independent and non-family directors is likely to result in family Board members being more accountable for their actions. Since Boards are expected to effectively challenge management, an excess of family involvement at Board and management levels will unnecessarily restrict the Board's ability to exercise its role effectively. In fact, in line with the arguments of Goh, Rasli and Khan (2014), most interviewees indicated that the effectiveness of such Boards' monitoring function tends to be questioned in such circumstances. Moreover, appointing a majority of independent directors who are incapable of properly discharging their duties will not in itself lead to enhanced Board performance. In fact, as rightly underlined by an LFBrep, one may even be deceived by a majority of independent directors, as this may be used to convey a fictional image of professionalism.

\section{c) What Are the Implications of Appointing Family Board Members?}

Board members are expected to comply with the obligations imposed by the Companies Act and the Listing Rules. However, directors could end up being 
influenced by the group that appointed them, especially in an FB setting. This point is supported by Ponomareva and Ahlberg (2016) as well as most interviewees. Board members appointed by the family may be much more willing to exert a degree of preference towards the desires of the controlling family due to reluctance to go against the wishes of the majority. This may result in situations whereby nonfamily directors will only be willing to intervene if the matter in question directly influences their personal intentions or reputation.

Furthermore, family relations in the boardroom may lead to increased tensions among family directors from different factions of the family, possibly disturbing Board performance. In the event of conflicts, as rightly explained by several interviewees, if the cause for such conflict is associated with business operations, the Board may be expected to promptly arrive at a solution. In such circumstances, the role of independent directors may turn out to be critical, as their view is often considered as objective and purely professional. On the other hand, if the cause for conflict is associated with family dynamics, the Board is not an adequate venue for resolving such issues. Moreover, the Code holds that the Board should perform annual self-evaluations. However, family relations at Board level are likely to compromise the effectiveness of such evaluations, as certain issues may deliberately remain concealed or overlooked. Therefore, a reasonable balance between family and non-family Board members may be suitable in this regard.

d) What Are the Implications of Appointing Family Members in Senior Management Positions?

Cadbury (2000) suggests that the entity grows, family and non-family members shall be presented with equal engagement and growth opportunities. However, as indicated by most LNFBreps, this is not something which family executives will accept with delight. This resistance generally originates from family members' attitude of ownership and entitlement towards the business. However, it may take years after listing for family executives to appreciate that, given the public stake, the business has ceased to be the "family jewel" and that they need to adjust accordingly - that is, to accept their mandate to properly execute business dealings alongside other executives. One way to facilitate this could be working towards establishing a culture of power and knowledge while the entity is still in its pre-listing phase. When engaging individuals to senior management roles, imposing contractual time limits of say 3 to 5 years tends to be more easily effected in the case of outsiders rather than in the case of family members. For the benefit of the entity itself, if senior positions are expected to be perpetual, the individuals appointed to such roles shall be competent and remain well informed about changes in the market in order to maintain competitiveness. Nevertheless, some interviewees insisted on the importance of "fresh blood" after a number of years.

e) What Are the Implications of Having a Family Chairman or CEO?

Apart from having family members involved in directorships and the management team, it is common for the founding family to occupy the post of Chairman, CEO, or 
in rare cases, even both. Provided that such roles are critical for the CG structure of an entity, LFBs should consider the implications that such family relations may have on the adequate execution of such roles as well as on the entity's performance.

First, given the sensitivity associated with terminating a family member's contract, most interviewees indicated that having a family CEO tends to put the Board in an uncomfortable position if they are not satisfied with such CEO's performance. Matters will become even more complicated if such CEO is related to several Board members. This may occur despite that, in theory, the Board shall be composed of professional individuals whose integrity and judgment is not prejudiced by familyties. In such circumstances, any delays by the Board with respect to hiring or firing a CEO for the sake of respecting the family will turn out to be detrimental to the business. Furthermore, most LNFBreps suggested that a CEO is more likely to exert a lenient attitude towards management team members with whom s/he shares a blood relationship.

Apart from this, in instances where the CEO is independent and the Chairman is a family member, the CEO might be reluctant to report the underperformance of family personnel. In such circumstances, the CEO's role becomes quite vulnerable as the CEO will attempt to maintain a healthy relationship with the Chairman and the Board. In fact, an LFBrep explained that bias in such circumstances would be inevitable as "blood is thicker than water".

To avoid the above-mentioned possibilities, most interviewees suggested that the CEO post needs to be independent of the family, especially if the Chairman is a family member him/herself. Similarly, Villalonga and Amit (2006) found that value will be created by restricting family involvement to only one of such roles. The appointment of a CEO shall be all about competence rather than anything else. If a particular candidate is resilient, open-minded, future-oriented, willing to voice his opinions and reject any form of favouritism, the entity's performance shall not be affected by whether the person concerned is a family member or not. However, such ideal behaviour is quite difficult to exert with blood relatives involved. Furthermore, there is no guarantee that having a family Chairman and an outside CEO will ensure that the CEO does not favour the family. With regards to the Chairman, most interviewees agreed with such post being occupied by a family member since the role is non-executive. It is, in fact, common for the Chairman's role to be occupied by a key family member, therefore, assuming that such a person has the best interest of the entity at heart, it is more likely that the visions set will be in line with those of the majority shareholders, though not necessarily with those of the minority shareholders.

Additionally, the Code attempts to clearly distinguish between the respective roles of the Chairman and CEO and to ensure that there is no duality in these roles. Yet, although these roles may not be performed by the same individual, there have been instances where blood-related individuals occupied such roles simultaneously. One 
main implication of such roles being family-related is that one party may effectively dominate, if not completely take over, the role of the other party. Such role infusion is clearly a stumbling block to good CG.

f) What Are the Implications of Having Board-Management Family Relationships? The extent to which family relationships within the Board and management levels affect business activities varies with the company's structure. In order for the Board to effectively discharge its supervisory duties over management, independence should be safeguarded either at Board or management level. In fact, in contrast with the conclusions of Poutziouris, Savva and Hadjielias (2015) that family relations between directors and management enhance entity performance, most LFBreps insisted that they attempt to avoid such family relations to minimize directors' bias towards management. Furthermore, in line with the findings of Chen, Gray and Nowland (2011), several LFBreps stressed that to safeguard the Board's ability to exercise effective control over management, Board independence shall be especially emphasized in business structures where family involvement within management is substantial.

Where management team members are blood-related with Board members, trust and transparency are perceived to be at stake. This was the view held by most participants. On the same note, Gersick et al. (1997) insisted that such family-ties are likely to increase the possibility of informal dealings between such parties, disregarding non-family members' right to be involved. However, several interviewees stressed that the entity's inbuilt culture and values, as well as the type of relationship which exists among the family members involved, determine the extent to which the notions of trust and transparency are influenced by such familyties. If healthy relations within the family exist, information sharing will be enhanced by having family members involved throughout the entity's strata. Alternatively, this may also lead to situations wherein family members would refrain from sharing information with each other or even worse, conspire to hide information from non-family members. It is not just a matter of having the necessary policies and procedures in place but also complied with. However, when such family relations exist, more value needs to be attached to market perceptions regarding the effectiveness of the Board and the professionalism of the management team.

\section{g) Will the Establishment of a Family Constitution and Family Institutions Enhance $C G$ ?}

LFBs are characterized by certain features, which distinguish them from their nonfamily counterparts. The purpose of having non-binding CG recommendations is to allow for the implementation of a CG structure adapted to the entity's specific requirements. In the light of this, LFBs need to appreciate that given their culture, some additional CG features may need to be adopted to ensure the formation of an adequate FGS. 
As defined by Neubauer and Lank (1998), the family constitution is a useful document which serves as a relevant guide to regulate intra-familiar relations and to prevent unnecessary conflicts. Therefore, such a document may serve as the tool which draws and emphasizes the fine line between family and business matters. Most interviewees specified that such document will only be effective if the family accepts what the document is intended to achieve. Nevertheless, having family members agreeing and documenting how certain family-related matters are to be dealt with will safeguard harmony and professionalism within business activities. In fact, in line with the findings of KPMG (2017), all interviewees agreed that the development of such a document will be beneficial for LFBs' operations.

However, despite this, it is evident that Maltese LFBs lack proper awareness regarding such benefits as none of the LFBs interviewed have a formally established family constitution in place. It is noteworthy that only one of the FB reps was knowledgeable about the workings of such a structure.

Furthermore, in order to regulate the family's involvement in business matters, LFBs may consider the establishment of institutions such as the family assembly and council. In line with the findings of Brenes, Madrigal, and Requena (2009), most interviewees agreed that the formation of such bodies will promote a healthier relationship between the family and the business, support prompt intra-familiar conflict resolutions and promote unity among the family. Although once again, none of the LFBs interviewed have these institutions formally established, few LFBreps declared that they have legal structures in place which may serve a similar purpose, in the form of holding companies owned by family owners. This supports the observation made by Taylor Wessing (2014) that public companies are likely to form legal bodies in an attempt to regulate the level of control held by various interested parties.

Such arrangements may serve different purposes depending on the structure of the LFB concerned. However, whether family presence within the entity's affairs is quite substantial or rather scarce, the main purpose of establishing such governance bodies is to provide a platform through which family members are allowed to voice their views and arrive at unified visions which will be presented to the Board or the AGM. Therefore, such structures may serve as communication media between the family and the business and the resulting proposals emanating from such structures are not decisive.

With regards to the establishment of a family office, one LFBrep explained that such a structure is not adequate for listed companies, as within such governance body "confidentiality and secrecy are the order of the day". This contrasts with the views held by Forbes (2013), Gray (2011) and most interviewees, suggesting that the use of a family office may prevent potential intra-familiar conflicts as a result of the management and the distribution of family wealth by entrusting such matters within the hands of family members or even non-family consultants. Family offices are 
probably most applicable for exceptionally wealthy families in business and therefore not necessarily relevant to all Maltese LFBs.

\section{The Maltese Regulatory Framework}

\section{a) Does the Code Fulfil the Needs of All MLCs?}

The CG principles included in the Code are quite generic in nature. However, this universality is intentional, aiming to encourage MLCs to interpret and implement such recommendations depending on the entity's structure. Consequently, many interviewees argued that given its broad nature, the Code successfully caters for the circumstances of all companies having their equities listed on the MSE, irrespective of whether they are family-controlled or otherwise. This implies that a number of MLCs do not acknowledge that there are any CG implications arising from the distinctive features associated with LFBs. On the other hand, several interviewees stressed that the Code's generic nature limits its applicability to the specific needs of LFBs. Although the CG principles are capable of serving as a relevant guideline if properly adapted to an entity's structure, whether or not such careful implementation is being done in practice is questionable. Consequently, if LFBs fail to determine the additional CG measures required to reflect their distinctive business structure, the professionalism attached to such entity's activities and the suitability of several business practices are likely to be challenged.

\section{b) How Can the Code be Made More Effective with Regards to LFBs?}

Family Board membership is a common LFB feature which may interrupt effective Board performance. However, despite the overall agreement of LNFBreps with respect to a recommended proportion of family members sitting on the Board and its subcommittees, mainly the Nomination and Remuneration committees, in general, LFBreps did not find such recommendation necessary, stating that the Code already tackles this issue. In fact, such a Code amendment, if effected, was considered to be rather discriminatory and several interviewees re-emphasised that what is more important is that Board membership is purely based on competence. However, the point might have easily been missed that the objective of such proportions is to establish adequate safeguards towards the interests of non-family minority shareholders. The Code also invites Board members to review the performance of the Board itself and that of its subcommittees on a yearly basis. However, family relations at Board level are likely to raise questions about the effectiveness of such evaluations. Consequently, one LFBrep suggested that appointing a team of external consultants to assist in these evaluations is likely to portray a message of professionalism and good governance. If such consultants are perceived as independent, their observations and concerns regarding the Board's effectiveness and the overall governance structure, are likely to be more valued. This is likely to reflect positively on the market perceptions towards the entity's best practice.

Furthermore, the Code recommends the appointment of independent NEDs. When assessing directors' independence, there are considerations which go beyond family 
relationships. Yet, the latter remains a relevant factor because for a person to be considered as truly independent, such individual shall be free from any social and financial ties with the family and the business. Garcìa-Ramos and Garcia-Olalla (2011) explain that in certain instances, the founding family may attempt to appoint directors who are deceitfully presented as independent in order to retain family dominance over the Board. In such circumstances, the performance of the Board and its subcommittees will be affected negatively. To counteract this, the Listing Authority may need to assign personnel to be responsible specifically to ensure that all such entities have a suitable proportion of truly independent directors and that such directors are properly discharging their duties.

Additionally, several interviewees also recommended the absence of family involvement in senior management positions. The rationale behind limiting family involvement to non-executive positions is to further limit family influence on dayto-day business operations. Furthermore, in view of propositions raised earlier, several interviewees agreed that the Code should recommend a no blood relationship between the Chairman and the CEO. Few LFBreps emphasized the importance of having the CEO engaged on a definite contract. Provided that the CEO's appointment is supposedly purely competence-based, the Board should thus be provided with the opportunity to evaluate the CEO's performance and to decide whether as to reappoint. This also enhances the CEO's drive towards continuously proving suitability for that post, given his/her consciousness that a suboptimal performance may lead to not being reappointed for another term.

Moreover, although the Code refers to the responsibility of the Board, the CEO and the Nomination Committee with respect to succession planning for the Board and senior management, some interviewees highlighted that this is often disregarded and a succession plan is rarely developed. Given the added sensitivity attached to role succession in FBs, the Code needs to be more specific and detailed in this regard in order to minimise the possibility of conflicts and disruption of business operations when a key person steps down. Apart from this, having a pre-determined succession plan will enable the successor to be properly trained in preparation for taking on a significant role, which is likely to result in a smoother transition both for the individual as well as for the entity itself.

It was also noted that although most interviewees had not ever to date considered the introduction of family constitution and/or institutions within their company, they were not averse to such mechanisms, so probably it is more a question of lack of awareness on the potential of such mechanisms. In order to tackle this, an interviewee suggested for a standard family constitution template to be drafted and attached to the Code together with recommendations on the composition and functions of the family assembly, council and office.

Finally, another relevant suggestion was for the need for educational programmes to raise collective awareness on the responsibility and accountability changes 
experienced when an entity decides to list. Given the public interest, the transition to listing necessitates adherence to more regulations, accountability and best practice market expectations.

Upon listing, the traditional mindset of patriarchs who founded the FB needs to be revised and commonly, this is far from an easy task. Of course, education programmes could help to engineer the needed change. Therefore, to ensure a smooth transition and successful continuance after listing, educational programs about what listing entails should be held. This may involve the engagement of foreign professionals to deliver sessions explaining the purpose, structure and workings of family constitutions and institutions and presenting actual case studies portraying the potential benefits gained from such structures. Furthermore, such sessions may also present stakeholders with specifically relevant advice related to successful response to the new directions in governance. Such sessions may assist in safeguarding professionalism throughout business operations and also maintaining positive market perceptions.

c) Will Recommendations Specific to LFBs Enhance Such Entities' CG?

Despite respondents' initial opposition to LFB/LNFB Code distinctions, most interviewees actually agreed to most recommendations presented to them. However, some interviewees still maintained that the addition of specific LFB recommendations would be discriminatory and a discouragement for FBs to list. Given the small size of Malta, family relationships are common in any business structure, not necessarily FBs. Therefore, several interviewees emphasized that if the Code was eventually to be made compulsory, such LFB provisions would, in any case, need to remain as optional. They also stressed that such provisions would have to be made applicable to any scenario where material family relations exist, whether in LFBs or LNFBs.

\section{Conclusions}

The authors conclude that Maltese LFBs do not as yet acknowledge the significance of their distinctive features and the implications of such features on their CG structures. As a result, the application of specific structures related to FBs, in particular, the family constitution and the family institutions are as yet not to be found. Several characteristics associated with FBs were ascertained. A number of these - namely non-economic goals, the permanence of family-related positions and the illiquidity of shares - were identified as being more specifically related to LFBs than other characteristics - namely a longer-term perspective and the varying levels of trust related to them. Such characteristics contribute to both the strengths and weaknesses of CG in LFBs. However, overall, LFBreps considered the various characteristics to be resulting in more disadvantages than advantages in their CG in relation to the CG situation in LNFBs. 
The three main parties forming the bulk of a company's CG structure were examined, these being Board members, executives and family shareholders. The study established that, prior to appointing Board members, LFBs consider several matters which are disregarded by LNFBs. Features such as family relations and bonds, previous experiences in FB directorships and tolerance for family control are taken into account as a particular type of Board composition incorporating family members is commonly sought. Moreover, it is clear Maltese LFBs attempt to keep family involvement in executive positions to a minimum in an effort to maintain Board independence.

Family involvement in such positions was, therefore, less preferred and frequent than those at Board level. In particular, the appointment of a family CEO was perceived as being far less ideal than that of a family non-executive Chairman. This study also found that, with regards to family involvement in senior positions, too much attention is directed toward the professionalism of the individuals concerned. However, the perceptions of other market players on the competencies of such individuals - which may not necessarily be positive - are not sufficiently taken into account in such appointments. Moreover, this study concludes that family shareholders in Maltese LFBs do not as yet consider the possible introduction of particular CG measures - such as the family constitution, assembly, council and office - that attempt to assist FBs in managing family owners' involvement in business affairs. This is mostly caused by the lack of awareness of the advantages of such governance mechanisms.

The authors also established that an LFB/LNFB distinction in the Code would be considered as discriminatory particularly by LFBs themselves and could, therefore, discourage new FBs from considering listing. Despite this, interviewees agreed that most of the Code recommendations presented to them - such as the introduction of the family constitution and institutions as referred to above, the avoidance of a Chairman/CEO blood relationship and an emphasis on succession planning at both Board and executive levels - are steps towards better practices. Yet, if such added provisions were to become part of the Code, interviewees insisted that they should be applicable to all MLCs wherever relevant.

All the efforts of a founding family may be easily undone by the unchecked behaviour of their successors if these fail to delve in senior management or Board positions without proper induction. In fact, as Baron Nathan de Rothschild, member of a well-known banking family, warned: "It requires a great deal of boldness and a great deal of caution to make a great fortune; and when you have got it, it requires 10 times more wit to keep it" (Cowles, 1973).

\section{References:}

Aguilera, R.V. and Jackson, G. 2010. Comparative and International Corporate Governance. The Academy of Management Annals, 4(1), 485 - 556. 
Anderson, R.C. and Reeb, D.M. 2004. Board Composition: Balancing Family Influence in S\&P 500 Firms. Administrative Science Quarterly, 49(2), 209 - 237.

Anderson, R.C. and Reeb, D.M. 2003. Founding-Family Ownership and Firm Performance: Evidence from the S\&P 500. Journal of Finance, 58(3), 1301 - 1328.

Astrachan, J.H., Klein, S.B. and Smyrnios, K.X. 2002. The F-PEC Scale of Family Influence: A Proposal for Solving the Family Business Definition Problem1. Family Business Review, 15(1), 45 - 58.

Athwal, R. 2017. Unleash Your Family Business DNA: Building a family legacy that lasts generations. London: RTS Books.

Barrett, M. 2014. Theories to define and understand family firms. The University of Wollongong. Available at: <http://ro.uow.edu.au/cgi/viewcontent.cgi?article=1397\&context=buspapers>

Barnett, T. and Kellermanns, F.W. 2006. Are We Family and Are We Treated as Family? Nonfamily Employees' Perceptions of Justice in the Family Firm. Entrepreneurship Theory and Practice, 30(6), 837 - 854.

Barontini, R. and Caprio, L. 2006. The Effect of Family Control on Firm Value and Performance: Evidence from Continental Europe. European Financial Management, 12(5), 689-723.

Barrow, L.M. 2004. A Hermeneutic Phenomenological Study of Philanthropies Leadership. $\mathrm{Ph}$. D. University of Phoenix. Available at: <http://www.bookpump.com/dps/pdfb/1122373b.pdf>

Brenes, E.R., Madrigal, K. and Requena, B. 2011. Corporate governance and family business performance. Journal of Business Research, 64(3), 280 - 285.

Braun, V. and Clarke, V. 2006. Using thematic analysis in psychology. Qualitative

Research in Psychology, 3(2), 77-101, DOI: 10.1191/1478088706qp063oa,

URL: http://dx.doi.org/10.1191/1478088706qp063oa.

Cadbury, A. 2000. Family Firms and their Governance Creating Tomorrow's Company from Today's. [pdf] Great Britain: Egon Zehnder International. Available at: $<$ http://www.ecseonline.com/PDF/Cadbury\%20\%20Family\%20Firms\%20and\%20their\%20Governance.pdf>

Calder, A. 2008. Corporate governance a practical guide to the legal frameworks and international codes of practice. London: Kogan Page.

Cambridge Family Enterprise Group, 2018. How Three Circles Changed the Way We Understand Family Business. [online] Available at: <https://cfeg.com/library/howthree-circles-changed-the-way-we-understand-family-business.asp?n=415>

Cannella, A.A. Jr., Jones, C.D. and Withers, M.C. 2015. Family- versus Lone-FounderControlled Public Corporations: Social Identity Theory and Boards of Directors. Academy of Management Journal, 58(2), 436 - 459.

Cennamo, C., Berrone, P., Cruz, C. and Gómez-Mejía, L.R. 2012. Socioemotional Wealth and Proactive Stakeholder Engagement: Why Family-Controlled Firms Care More about their Stakeholders. Entrepreneurship Theory and Practice, 36(6), 1153 1173 .

Cheffins, B.R. 2011. The History of Corporate Governance. [pdf] European Corporate Governance Institute. Available at: <file:///C:/Users/Asus/Downloads/SSRN-id1975404\%20(4).pdf>

Chen, E.T., Gray, S. and Nowland, J. 2011. Family involvement and family firm performance. [pdf] Hong Kong: City University of Hong Kong. Available at: <http://aicg.org/_res/aicg/etc/Family_involvement_and_family_firm_performance _John_Nowland.pdf $>$ 
Chrisman, J.J., Sharma, P., Steier, L.P. and Chua, J.H. 2013. The Influence of Family Goals, Governance, and Resources on Firm Outcomes. Entrepreneurship Theory and Practice, 37(6), 1249 - 1261.

Coffee, J.C. 2005. A Theory of Corporate Scandals: Why the USA and Europe Differ. Oxford Review of Economic Policy, 21(2), 198 - 211.

Cowles, V. 1973. The Rothschilds: A Family Fortune. New York: Alfred A Knopf.

Creswell, J.W. 2015. A Concise Introduction to Mixed Methods Research. USA: SAGE Publications, Inc.

Daspit, J.J., Chrisman, J.J., Sharma, P., Pearson, A.W. and Long, R.G. 2017. A Strategic Management Perspective of the Family Firm: Past Trends, New Insights, and Future Directions. Journal of Managerial Issues, 29(1), 6- 29.

Davis, J.A. 2001. The Three Components of Family Governance. [online] Available at: < https://hbswk.hbs.edu/item/the-three-components-of-family-governance>

Davis, J.H., Schoorman, F.D. and Donaldson, L. 1997. Toward a Stewardship Theory of Management. The Academy of Management Review, 22(1), 20 - 47.

Debicki, B.J., Van de Graaff, R. and Sobczak, M. 2017. Socioemotional Wealth and Family Firm Performance: A Stakeholder Approach. Journal of Managerial Issues, 29(1), $82-111$.

Dènìz-Dènìz, M.C., Cabrera-Suàrez, M.K. and Martìn-Santana, J.D. 2018. Family firms and the interests of non-family stakeholders: The influence of family managers' affective commitment and family salience in terms of power. Business Ethics: A European Review, 27(1), 15 - 28.

Dibra, R. 2016. Corporate Governance Failure: The Case of Enron and Parmalat. European Scientific Journal, 12(16), 283 - 290.

Eddleston, K.A., Chrisman, J.J., Steier, L.P. and Chua, J.H. 2010. Governance and Trust in Family Firms: An Introduction. Entrepreneurship Theory and Practice, 34(6), 1043 $-1056$.

Fama, E.F. 1980. Agency problems and the theory of the firm. Journal of Political Economy, 88(2), $288-307$.

Farrugia, N. 2010. The Issue of Corporate Governance in Family-Run Businesses. LL.D. The University of Malta.

Filatotchev, I., Jackson, G. and Nakajima, C. 2013. Corporate governance and national institutions: A review and emerging research agenda. Asia Pacific Journal of Management, 30(4), $965-986$.

Finance Malta, 2015. Malta enacts Family Business Legislation. [online] Finance Malta. Available at: <https://www.financemalta.org/publications/articlesinterviews/articles-and-interviews-detail/malta-enacts-family-businesslegislation/>

Finkelstein, S., Hambrick, D.C. and Cannella A.A. 2009. Strategic Leadership: Theory and Research on Executives, Top Management Teams and Boards. New York: Oxford University Press.

Forbes, 2013. What Is A Family Office? [online] Available at: <https://www.forbes.com/sites/russalanprince/2013/05/22/what-is-a-familyoffice/\#2e4cea277708>

Galletta, A. 2013. Mastering the Semi-Structured Interview and Beyond: From Research Design to Analysis and Publication. New York and London: New York University Press. 
Gapper, J. 2018. Millennial heirs have to show their worth. The Financial Times, [online] 25 April. Available at: <https://www.ft.com/content/f14c1510-47b1-11e8-8ae94b5ddcca99b3\#comments-anchor>

García-Ramos, R., Díaz-Díaz, B. and García-Olalla, M. 2017. Independent directors, large shareholders and firm performance: the generational stage of family businesses and the socioemotional wealth approach. Review of Managerial Science, 11(1), $119-156$.

Garcìa-Ramos, R. and Garcìa-Olalla, M. 2011. Board characteristics and firm performance in public founder- and nonfounder-led family businesses. Journal of Family Business Strategy, 2(4), $220-231$.

Gersick, K.E., Davis, J.A., Hampton, M.M. and Lansberg, I. 1997. Generation to Generation: Life Cycles of the Family Business. USA: Owner Managed Business Institute.

Gill, A. and Obradovich, J.D. 2012. The Impact of Corporate Governance and Financial Leverage on the Value of American Firms. International Research Journal of Finance and Economics, [online] Available at $<$ http://digitalcommons.liberty.edu/cgi/viewcontent.cgi?article $=1025 \&$ context $=$ bu si_fac_pubs>

Goel, S., Voordeckers, W., van Gils, A. and van den Heuvel, J. 2013. CEO's empathy and salience of socioemotional wealth in family SMEs - The moderating role of external directors. Entrepreneurship \& Regional Development, 25(3-4), 111 - 134.

Goh, C.F., Rasli, A. and Khan, S.U.R. 2014. CEO duality, board independence, corporate governance and firm performance in family firms: Evidence from the manufacturing industry in Malaysia. Asian Business \& Management, 13(4), 333 357.

Gómez-Mejía, L.R., Cruz, C., Berrone, P. and De Castro, J. 2011. The Bind that Ties: Socioemotional Wealth Preservation in Family Firms. The Academy of Management Annals, 5(1), 653-707.

Gómez-Mejía, L.R., Haynes, K.T., Núñez-Nickel, M., Jacobson, K.J.L. and MoyanoFuentes, J. 2007. Socioemotional Wealth and Business Risks in Family-controlled Firms: Evidence from Spanish Olive Oil Mills. Administrative Science Quarterly, 52(1), 106-137.

Gòmez-Mejìa, L.R., Núñez-Nickel, M. and Gutierrez, I. 2001. The Role of Family Ties in Agency Contracts. The Academy of Management Journal, 44(1), 81 - 95.

Gray, L. 2011. The Three Forms of Governance: A New Approach to Family Wealth Transfer and Asset Protection, Part III. The Journal of Wealth Management, 14(1), $41-54$.

Hnilica, J. and Machek, O. 2015. Toward a Measurable Definition of Family Business: Surname Matching and its Application in the Czech Republic. International Advances in Economic Research, 21(1), 119 - 120.

International Finance Corporation (IFC). 2011. IFC Family Business Governance Handbook. 3rd ed. [e-book] Pennsylvania: IFC. Available at:

<https://www.ifc.org/wps/wcm/connect/6a9001004f9f5979933cff0098cb14b9/FamilyBusine ssGovernance_Handbook_English.pdf?MOD=AJPERES>

Jain, B.A. and Shao, Y. 2015. Family Firm Governance and Financial Policy Choices in Newly Public Firms. Corporate Governance: An International Review, 23(5), 452 $-468$.

Jaskiewicz, P. and Klein, S. 2007. The impact of goal alignment on board composition and board size in family businesses. Journal of Business Research, 60(10), 1080 1089. 
Jensen, M.C. and Meckling, W.H. 1976. Theory of the firm: Managerial behaviour, agency costs and ownership structure. Journal of Financial Economics, 3(4), 305 - 360.

Kidwell, R.E., Kellermanns, F.W. and Eddleston, K.A. 2012.

Harmony, Justice, Confusion, and Conflict in Family Firms: Implications for Ethical Climate and the "Fredo Effect". Journal of Business Ethics, 106(4), 503 517.

Klein, P., Shapiro, D. and Young, J. 2005. Corporate Governance, Family Ownership and Firm Value: the Canadian evidence. Corporate Governance: An International Review, 13(6), 769 - 784.

KPMG. 2010. Constructing a Family Constitution. [online] Australia: KPMG. Available at: $<$ http://www.fambiz.org.au/wp-content/uploads/Constructing-a-FamilyConstitution-KPMG.pdf>

KPMG. 2017. A family constitution can increase family cohesion and business connectivityleading to economic success. [online] Available at: <https://home.kpmg.com/xx/en/home/insights/2017/06/family-strategy-increasesfamily-cohesion-and-business-connectivity-leading-to-economic-success.html>

Kraiczy, N. 2013. Innovations in Small and Medium-Sized Family Firms. An Analysis of Innovations Related Top Management Team Behaviours and Firm-Specific Characteristics. Vallendar: Springer Gabler.

Kuruppuge, R.V. and Ekanayake, A. 2016. An Analytical Model to Explain the Governance of Family Owned Businesses. Journal of Intercultural Management, 8(1), 51 - 69.

Le Breton-Miller, I. and Miller, D. 2009. Agency vs. stewardship in public family firms: A social embeddedness reconciliation. Entrepreneurship Theory and Practice, 33(6), $1169-1191$.

Lee, J. 2006. Family Firm Performance: Further Evidence. Family Business Review, 19(2), $103-114$.

Mackey, A. and Gass, S.M. 2016. Second Language Research: Methodology and Design. 2nd ed. New York: Routledge.

Martínez-Mesa, J., González-Chica, D.A., Duquia, R.P., Bonamigo, R.R. and Bastos, J.L. 2016. Sampling: how to select participants in my research study? Anais Brasileiros de Dermatologia, 91(3), 326 - 330.

McIntosh, M.J. and Morse, J.M. 2015. Situating and Constructing Diversity in SemiStructured Interviews. Global Qualitative Nursing Research, 2, 1- 12.

Miller, D., Amore, M.D., Le Breton-Miller, I. and Minichilli, A. (in press). Strategic distinctiveness in family firms: Firm institutional heterogeneity and configurational multidimensionality. Journal of Family Business Strategy. (Accepted for publication February 2018).

Miller, D. and Le Breton-Miller, I 2007. Kicking the habit - Broadening our horizons by studying family businesses. Journal of Management Inquiry, 16(1), 27 - 30.

Miller, D. and Le Breton-Miller, I. 2006. Family Governance and Firm Performance: Agency, Stewardship, and Capabilities. Family Business Review, 19(1), $73-87$.

Miller, D. and Le Breton-Miller, I. 2005. Managing for the Long Run: Lessons in Competitive Advantage from Great Family Businesses. Boston: Harvard Business School Press.

Miller, D. and Le Breton-Miller, I. 2003. Challenge versus Advantage in Family Business. Strategic Organisation, 1(1), $127-134$. 
Miller, D., Steier, L. and Le Breton-Miller, I. 2016. What Can Scholars of Entrepreneurship Learn from Sound Family Businesses? Entrepreneurship Theory and Practice, 40(3), $445-455$.

Mishra, C.S., Randøy, T. and Jenssen, J.I. 2001. The Effect of Founding Family Influence on Firm Value and Corporate Governance. Journal of International Financial Management \& Accounting, 12(3), 235 - 259.

Morse, J.M. 1995. The significance of saturation. Qualitative Health Research, 5(3), 147149.

Morse, J. M. and Niehaus, L. 2009. Mixed Method Design: Principles and Procedures. New York: Left Coast Press, Inc.

Mustakallio, M.A. 2002. Contractual and relational governance in family firms: Effects on strategic decision-making quality and firm performance. Ph. D. Helsinki University of Technology. Available at: <http://lib.tkk.fi/Diss/2002/isbn9512263335/isbn9512263335.pdf>

Mustakallio, M., Autio, E. and Zahra, S.A. 2002. Relational and Contractual Governance in Family Firms: Effects on Strategic Decision Making. Family Business Review, 15(3), $205-222$.

Neubauer, F. and Lank, A.G. 1998. The Family Business: Its Governance for Sustainability. London: Macmillan Press LTD.

Palinkas, L., Horwitz, S., Green, C., Wisdom, J., Duan, N. and Hoagwood, K. 2015. Purposeful Sampling for Qualitative Data Collection and Analysis in MixedMethod Implementation Research. Administration and Policy in Mental Health and Mental Health Services Research, 42(5), 533 - 544.

Pearson, A.W. and Marler L.E. 2010. A Leadership Perspective of Reciprocal Stewardship in Family Firms. Entrepreneurship Theory and Practice, 34(6), 1117 - 1124.

Pike, R. and Neale, B. 2009. Corporate Finance and Investment: Decisions and Strategies. 6th ed. Essex: Pearson Education Limited.

Ponomareva, Y. and Ahlberg, J. 2016. Bad governance of family firms: The adoption of good governance on the boards of directors in family firms. Ephemera: theory \& politics in organization, 16(1), $53-77$.

Poutziouris, P., Savva C.S. and Hadjielias, E. 2015. Family involvement and firm performance: Evidence from UK listed firms. Journal of Family Business Strategy, $6(1), 14-32$.

PWC. 2013. The Family Firm: Central to the success of the Middle East. [pdf] PWC. Available at: <https://www.pwc.com/m1/en/publications/documents/family-firmenglish.pdf >

PWC. 2012. Family firm: A resilient model for the 21st century. [pdf] PWC. Available at: <https://www.pwc.com/hu/en/publications/assets/family_business_survey.pdf>

Sarbah, A. and Xiao, W. 2015. Good Corporate Governance Structures: A Must for Family Businesses. Open Journal of Business and Management, 3, 40 - 57.

Saunders, M., Lewis, P., and Thornhill, A. 2007. Research Methods for Business Students. 4th ed. Essex: Pearson Education Limited.

Shleifer, A. and Vishny, R.W. 1997. A Survey on Corporate Governance. The Journal of Finance, 52(2), $737-783$.

Simon, D.G. and Hitt, M.A. 2003. Managing Resources: Liking Unique Resources, Management and Wealth Creation in Family Firms. Entrepreneurship Theory and Practice, 27(4), 339 - 358.

Steier, L.P. 2001. Family Firms, Plural Forms of Governance, and the Evolving Role of Trust. Family Business Review, 14(4), 353 - 367. 
Steier, L.P., Chrisman, J.J. and Chua, J.H. 2015. Governance Challenges in Family Businesses and Business Families. Entrepreneurship Theory and Practice, 39(6), 1265 - 1450.

Tagiuri, R. and Davis, J. 1996. Bivalent Attributes of the Family Firm. Family Business Review, 9(2), 199 - 208.

Taylor, W. 2014. The Family Constitution Guide- An introductory guide to Family Constitutions: their scope, impact and uses. [online] London: Taylor Wessing LLP. <file:///C:/Users/Asus/Downloads/Family_Constitution_Guide.pdf>

Villalonga, B. and Amit, R. 2006. How do family ownership, control and management affect firm value? Journal of Financial Economics, 80(2), 385 - 417.

Wallevik, K. 2009. Corporate Governance in Family Firms: The Norwegian Maritime Sector. $\mathrm{Ph}$. D. Copenhagen Business School. Available at: <http://openarchive.cbs.dk/bitstream/handle/10398/7901/Kristin_Wallevik.pdf?se quence $=1>$

Ward, J. L. 1997. Growing the Family Business: Special Challenges and Best Practices. Family Business Review, 10(4), 323 - 337.

Weiste, L.K. 2013. The role of family governance and family councils as a success factor for long-lasting family companies. Master's thesis. Aalto University School of Business. Available at: <https://slidex.tips/download/the-role-of-familygovernance-and-family-councils-as-a-success-factor-for-long-1 >

Wells, H. 2010. The Birth of Corporate Governance. Seattle University Law Review, 33(4), $1247-1292$.

Wilson, N., Wright, M. and Scholes, L. 2013. Family Business Survival and the Role of Boards. Entrepreneurship Theory and Practice, 37(6), pp.1369 - 1389. Available at: 〈http://dx.doi.org/10.1787/9789264236882-en>

\section{Regulatory:}

Cadbury, A. 1992. Report of the committee on the financial aspects of corporate governance. London: Gee.

European Commission. 2009. Overview of Family-Business-Relevant Issues: Research, Networks, Policy Measures and Existing Studies. [pdf] European Commission. <file:///C:/Users/Asus/Downloads/family_business_expert_group_report_en.pdf> Malta Financial Services Authority. 2010. The Code of Principles of Good Corporate Governance for Listed Entities. OECD, 2015. G20/OECD Principles of Corporate Governance. Paris: OECD Publishing

\section{Appendix:}

This appendix contains the interview schedule that was used during the interviews conducted to guide the discussion with the interviewees on the desired topics. The number of responses for each Likert scale statement/question is presented, distinguishing between the number of responses from LFBreps (G1) and LNFBreps (G2).

Section 1: Distinctive Features of Family-Controlled and Influenced Companies

The questions in this section are about various characteristics of family businesses. Characteristics of Listed Family Businesses

1.1 In family-controlled or influenced businesses, family members may be involved as owners, members of staff, managers or directors. In what ways is the entity's performance affected by such an involvement. 
1.2 Comment on whether such features serve as inherent characteristics of familycontrolled/influenced and how they might affect the performance of such entities:
i. Non-economic goals
ii. Permanent
Posts
iii.
Outlook
iv. Liquidity of shares $\quad$ v. Trust

\section{Strengths and Weaknesses of Family-Controlled or Influenced Companies}

\begin{tabular}{|c|c|c|c|c|c|c|c|c|c|c|c|}
\hline \multirow{3}{*}{\multicolumn{2}{|c|}{$\begin{array}{l}\text { 1.3 The following are } \\
\text { likely to serve as } \\
\text { advantages of } \\
\text { operating a family- } \\
\text { controlled/influenced } \\
\text { business. }\end{array}$}} & \multicolumn{10}{|c|}{ Number of Interviewees $=18$} \\
\hline & & \multicolumn{2}{|c|}{$\begin{array}{l}\text { Strongly } \\
\text { Disagree }\end{array}$} & \multicolumn{2}{|c|}{ Disagree } & \multicolumn{2}{|c|}{ Neutral } & \multicolumn{2}{|c|}{ Agree } & \multicolumn{2}{|c|}{$\begin{array}{l}\text { Strongly } \\
\text { Agree }\end{array}$} \\
\hline & & G1 & G2 & G1 & G2 & G1 & G2 & G1 & G2 & G1 & G2 \\
\hline \multicolumn{12}{|c|}{$\begin{array}{ll}\text { i. } & \text { Family members } \\
\text { involved in business } \\
\text { operations }\end{array}$} \\
\hline \multicolumn{12}{|c|}{$\begin{array}{l}\text { ii. Stronger relationships } \\
\text { with internal and } \\
\text { external stakeholders }\end{array}$} \\
\hline \multicolumn{12}{|c|}{$\begin{array}{l}\text { iii. Enhanced } \\
\text { commitment and } \\
\text { stability }\end{array}$} \\
\hline \multirow{3}{*}{\multicolumn{2}{|c|}{$\begin{array}{l}\text { 1.4 The following are likely } \\
\text { to serve as } \\
\text { disadvantages of } \\
\text { operating a family- } \\
\text { controlled/influenced } \\
\text { business. } \\
\end{array}$}} & \multicolumn{10}{|c|}{ Number of Interviewees $=18$} \\
\hline & & \multicolumn{2}{|c|}{$\begin{array}{l}\text { Strongly } \\
\text { Disagree }\end{array}$} & \multicolumn{2}{|c|}{ Disagree } & \multicolumn{2}{|c|}{ Neutral } & \multicolumn{2}{|c|}{ Agree } & \multicolumn{2}{|c|}{$\begin{array}{l}\text { Strongly } \\
\text { Agree }\end{array}$} \\
\hline & & $\mathbf{G}$ & G2 & G1 & G2 & G1 & G2 & G1 & G2 & G1 & G2 \\
\hline i. & Family conflicts & & & & & & & & & & \\
\hline \multicolumn{12}{|c|}{$\begin{array}{l}\text { ii. } \begin{array}{l}\text { Blind family } \\
\text { appointments }\end{array} \\
\end{array}$} \\
\hline & $\begin{array}{l}\text { Distinguishing between } \\
\text { family and non-family } \\
\text { employees }\end{array}$ & & & & & & & & & & \\
\hline
\end{tabular}

Please comment on your rating to statements 1.3 and 1.4, explaining your viewpoint on each statement.

Section 2: The Family Governance Structure

The questions in this section are about various components of the Family Governance System.

i. Board of Directors

Appointment of Board Members in Listed Family Businesses

\begin{tabular}{|l|l|l|l|l|l|}
\hline 2.1 & $\begin{array}{l}\text { Family owners would } \\
\text { encourage the } \\
\text { appointment of board }\end{array}$ & \multicolumn{3}{|l|}{ Number of Interviewees $=18$} \\
\cline { 2 - 6 } & $\begin{array}{l}\text { Strongly } \\
\text { Disagree }\end{array}$ & Disagree & Neutral & Agree & $\begin{array}{l}\text { Strongly } \\
\text { Agree }\end{array}$ \\
\hline
\end{tabular}




\begin{tabular}{|c|l|l|l|l|l|l|l|l|l|l|}
\hline nominees who: & & & & & & & & \\
\hline & G1 & G2 & G1 & G2 & G1 & G2 & G1 & G2 & G1 & G2 \\
\hline i. Are family members. & & & & & & & & & & \\
\hline $\begin{array}{l}\text { ii. Previously held family } \\
\text { business directorships. }\end{array}$ & & & & & & & & & & \\
\hline $\begin{array}{l}\text { iii. Will probably not } \\
\text { oppose family control. }\end{array}$ & & & & & & & & & & \\
\hline
\end{tabular}

\begin{tabular}{|c|c|c|c|c|c|c|c|c|c|c|}
\hline \multirow{3}{*}{$\begin{array}{l}\text { 2.2 Listed family businesses } \\
\text { appoint Board members } \\
\text { on the basis of: }\end{array}$} & \multicolumn{10}{|c|}{ Number of Interviewees $=18$} \\
\hline & \multicolumn{2}{|c|}{$\begin{array}{l}\text { Strongly } \\
\text { Disagree }\end{array}$} & \multicolumn{2}{|c|}{ Disagree } & \multicolumn{2}{|c|}{ Neutral } & \multicolumn{2}{|c|}{ Agree } & \multicolumn{2}{|c|}{$\begin{array}{l}\text { Strongly } \\
\text { Agree }\end{array}$} \\
\hline & G1 & G2 & G1 & G2 & G1 & G2 & G1 & G2 & G1 & G2 \\
\hline Experience. & & & & & & & & & & \\
\hline Professionalism. & & & & & & & & & & \\
\hline $\begin{array}{l}\text { iii. } \begin{array}{c}\text { Previous } \\
\text { appointments. }\end{array}\end{array}$ & & & & & & & & & & \\
\hline iv. $\quad$ Family relations. & & & & & & & & & & \\
\hline Family bonds. & & & & & & & & & & \\
\hline
\end{tabular}

The composition of the Board of Directors in Listed Family Businesses

\begin{tabular}{|c|c|c|c|c|c|c|c|c|c|c|}
\hline & \multicolumn{10}{|c|}{ Number of Interviewees $=18$} \\
\hline & \multicolumn{2}{|c|}{$\begin{array}{l}\text { Strongly } \\
\text { Disagree }\end{array}$} & \multicolumn{2}{|c|}{ Disagree } & \multicolumn{2}{|c|}{ Neutral } & \multicolumn{2}{|c|}{ Agree } & \multicolumn{2}{|c|}{$\begin{array}{l}\text { Strongly } \\
\text { Agree }\end{array}$} \\
\hline & G1 & G2 & G1 & G2 & G1 & G2 & G1 & G2 & G1 & G2 \\
\hline $\begin{array}{l}2.3 \text { A majority of non-family } \\
\text { directors safeguards } \\
\text { transparency and } \\
\text { accountability. }\end{array}$ & & & & & & & & & & \\
\hline $\begin{array}{l}2.4 \text { A higher proportion of } \\
\text { independent directors } \\
\text { increases the Board's } \\
\text { ability to exercise } \\
\text { effective control and } \\
\text { monitor executive } \\
\text { decision making. }\end{array}$ & & & & & & & & & & \\
\hline
\end{tabular}

Implications of Having Family Members Sitting on the Board

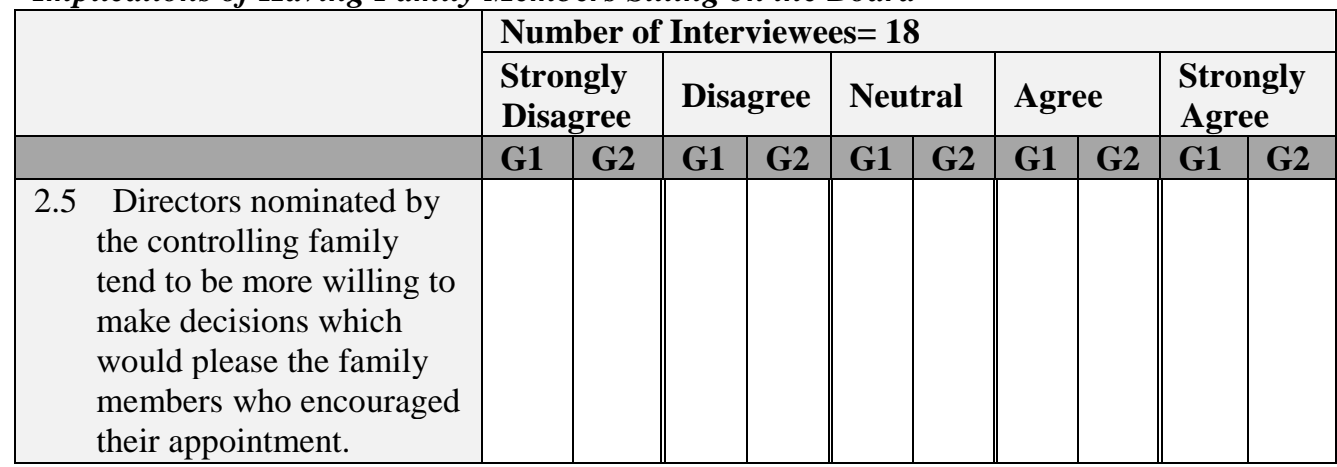


Please comment on your rating to statements 2.1 to 2.6, explaining your viewpoint on each statement.

\begin{tabular}{|c|c|c|c|c|c|c|c|c|c|c|}
\hline & \multicolumn{10}{|c|}{ Number of Interviewees $=18$} \\
\hline & \multicolumn{2}{|c|}{$\begin{array}{l}\text { Strongly } \\
\text { Disagree }\end{array}$} & \multicolumn{2}{|c|}{ Disagree } & \multicolumn{2}{|c|}{ Neutral } & \multicolumn{2}{|c|}{ Agree } & \multicolumn{2}{|c|}{$\begin{array}{l}\text { Strongly } \\
\text { Agree }\end{array}$} \\
\hline & G1 & G2 & G1 & G2 & G1 & G2 & G1 & G2 & G1 & G2 \\
\hline $\begin{array}{l}\text { Apart from their } \\
\text { monitoring role, directors } \\
\text { serving on listed family } \\
\text { businesses' Boards are } \\
\text { expected to act as a } \\
\text { means to resolve conflict } \\
\text { amongst family } \\
\text { executives. }\end{array}$ & & & & & & & & & & \\
\hline
\end{tabular}

ii. Senior Management

Appointment of Family Members to Senior Management Positions

\begin{tabular}{|c|c|c|c|c|c|c|c|c|c|c|}
\hline & \multicolumn{10}{|c|}{ Number of Interviewees $=18$} \\
\hline & \multicolumn{2}{|c|}{$\begin{array}{l}\text { Strongly } \\
\text { Disagree }\end{array}$} & \multicolumn{2}{|c|}{ Disagree } & \multicolumn{2}{|c|}{ Neutral } & \multicolumn{2}{|c|}{ Agree } & \multicolumn{2}{|c|}{$\begin{array}{l}\text { Strongly } \\
\text { Agree }\end{array}$} \\
\hline & G1 & G2 & G1 & G2 & G1 & G2 & G1 & G2 & G1 & G2 \\
\hline $\begin{array}{l}\text { 2.7 Family executives tend } \\
\text { to be rich in tacit } \\
\text { knowledge but lack } \\
\text { professional training and } \\
\text { previous work } \\
\text { experience outside the } \\
\text { entity. }\end{array}$ & & & & & & & & & & \\
\hline $\begin{array}{l}2.8 \text { Family executives tend } \\
\text { to find it difficult to } \\
\text { accept that they need to } \\
\text { share their power with } \\
\text { non-family executives. }\end{array}$ & & & & & & & & & & \\
\hline
\end{tabular}

\begin{tabular}{|l|l|l|l|l|l|l|l|l|l|l|l|l|}
\hline & \multicolumn{9}{|l|}{ Number of Interviewees= 18 } \\
\cline { 2 - 9 } & $\begin{array}{l}\text { Strongly } \\
\text { Disagree }\end{array}$ & \multicolumn{2}{|l|}{ Disagree } & \multicolumn{2}{|l|}{ Neutral } & \multicolumn{2}{|c|}{ Agree } & \multicolumn{2}{|l|}{$\begin{array}{l}\text { Strongly } \\
\text { Agree }\end{array}$} \\
\hline & G1 & G2 & G1 & G2 & G1 & G2 & G1 & G2 & G1 & G2 \\
\hline 2.9 & $\begin{array}{l}\text { When appointing top } \\
\text { executives, family } \\
\text { owners will be } \\
\text { reluctant to engage } \\
\text { outsiders in senior } \\
\text { positions as an attempt } \\
\text { to retain family } \\
\text { control. }\end{array}$ & 0 & 0 & 3 & 0 & 2 & 2 & 2 & 9 & 0 & 0 \\
\hline
\end{tabular}




\begin{tabular}{|c|c|c|c|c|c|c|c|c|c|c|c|}
\hline \multirow[t]{3}{*}{2.10} & \multirow{3}{*}{$\begin{array}{l}\text { Appointing family } \\
\text { members in top } \\
\text { executive roles will } \\
\text { result in: }\end{array}$} & \multicolumn{10}{|c|}{ Number of Interviewees $=18$} \\
\hline & & \multicolumn{2}{|c|}{$\begin{array}{l}\text { Strongly } \\
\text { Disagree }\end{array}$} & \multicolumn{2}{|c|}{ Disagree } & \multicolumn{2}{|c|}{ Neutral } & \multicolumn{2}{|c|}{ Agree } & \multicolumn{2}{|c|}{$\begin{array}{l}\text { Strongly } \\
\text { Agree }\end{array}$} \\
\hline & & G1 & G2 & G & G2 & G1 & G2 & G1 & G2 & G1 & G2 \\
\hline & $\begin{array}{l}\text { Added commitment } \\
\text { towards the entity's } \\
\text { long-term prosperity. }\end{array}$ & & & & & & & & & & \\
\hline ii. & $\begin{array}{l}\text { Added continuity } \\
\text { and stability as they tend } \\
\text { to retain their position } \\
\text { for longer periods. }\end{array}$ & & & & & & & & & & \\
\hline
\end{tabular}

\section{Implications of Having a Family CEO}

\begin{tabular}{|c|c|c|c|c|c|c|c|c|c|c|}
\hline \multirow{3}{*}{$\begin{array}{l}2.11 \text { Having a family- } \\
\text { related CEO will result } \\
\text { in: }\end{array}$} & \multicolumn{10}{|c|}{ Number of Interviewees $=18$} \\
\hline & \multicolumn{2}{|c|}{$\begin{array}{l}\text { Strongly } \\
\text { Disagree }\end{array}$} & \multicolumn{2}{|c|}{ Disagree } & \multicolumn{2}{|c|}{ Neutral } & \multicolumn{2}{|c|}{ Agree } & \multicolumn{2}{|c|}{$\begin{array}{l}\text { Strongly } \\
\text { Agree }\end{array}$} \\
\hline & G1 & G2 & G1 & G2 & G1 & G2 & G1 & G2 & G1 & G2 \\
\hline $\begin{array}{l}\text { i. } \begin{array}{l}\text { CEO termination to } \\
\text { become unlikely even } \\
\text { when justifiable. }\end{array} \\
\end{array}$ & & & & & & & & & & \\
\hline $\begin{array}{l}\text { ii. Decisions and actions } \\
\text { being unduly } \\
\text { influenced by the } \\
\text { family. }\end{array}$ & & & & & & & & & & \\
\hline
\end{tabular}

Please comment on your rating to statements 2.7 to 2.11, explaining your viewpoint on each statement.

The Effects on Business Performance When Appointing a Family Chairman/CEO

2.12 Will the overall business performance and decision-making be affected if a listed family business appoints a:

i. family CEO;

ii. family Chairman?

iii. Board-Management Family Relationships

\begin{tabular}{|c|c|c|c|c|c|c|c|c|c|}
\hline \multirow{3}{*}{\multicolumn{2}{|c|}{$\begin{array}{l}2.13 \text { Family ties between } \\
\text { directors and } \\
\text { management may } \\
\text { result in: }\end{array}$}} & \multicolumn{7}{|c|}{ Number of Interviewees $=18$} & \\
\hline & & \multicolumn{2}{|c|}{$\begin{array}{l}\text { Strongly } \\
\text { Disagree }\end{array}$} & \multicolumn{2}{|c|}{ Disagre } & \multicolumn{3}{|c|}{ Neutral } & $\begin{array}{l}\text { Strongly } \\
\text { Agree }\end{array}$ \\
\hline & & G1 & $\mathbf{G}^{\prime}$ & $\mathbf{G}$ & $\mathbf{G}$ & $\mathbf{G}$ & & & G2 \\
\hline \multicolumn{10}{|c|}{$\begin{array}{l}\text { i. Directors making } \\
\text { decisions unduly } \\
\text { favouring } \\
\text { management. }\end{array}$} \\
\hline & $\begin{array}{l}\text { Strengthened trust ar } \\
\text { information sharing } \\
\text { amongst such parties }\end{array}$ & & & & & & & & \\
\hline
\end{tabular}




\begin{tabular}{|c|c|c|c|c|c|c|c|c|c|c|}
\hline \multirow{3}{*}{$\begin{array}{l}2.14 \text { Family ties between } \\
\text { directors and } \\
\text { management may } \\
\text { jeopardise: }\end{array}$} & \multicolumn{10}{|c|}{ Number of Interviewees $=18$} \\
\hline & \multicolumn{2}{|c|}{$\begin{array}{l}\text { Strongly } \\
\text { Disagree }\end{array}$} & \multicolumn{2}{|c|}{ Disagree } & \multicolumn{2}{|c|}{ Neutral } & \multicolumn{2}{|c|}{ Agree } & \multicolumn{2}{|c|}{$\begin{array}{l}\text { Strongly } \\
\text { Agree }\end{array}$} \\
\hline & G1 & G2 & G1 & G2 & G1 & G2 & G1 & G2 & G1 & G2 \\
\hline Internal transparency. & & & & & & & & & & \\
\hline $\begin{array}{l}\text { ii. External } \\
\text { transparency. }\end{array}$ & & & & & & & & & & \\
\hline
\end{tabular}

\begin{tabular}{|c|c|c|c|c|c|c|c|c|c|c|}
\hline 2.15 $\begin{array}{l}\text { Family-ties between } \\
\text { directors and } \\
\text { management: }\end{array}$ & \multicolumn{9}{|l|}{ Number of Interviewees= 18 } \\
\cline { 2 - 9 } & $\begin{array}{l}\text { Strongly } \\
\text { Disagree }\end{array}$ & \multicolumn{2}{|l|}{ Disagree } & \multicolumn{2}{|l|}{ Neutral } & \multicolumn{2}{|l|}{ Agree } & \multicolumn{2}{|l|}{$\begin{array}{l}\text { Strongly } \\
\text { Agree }\end{array}$} \\
\hline & G1 & G2 & G1 & G2 & G1 & G2 & G1 & G2 & G1 & G2 \\
\hline i. $\begin{array}{l}\text { Enhance Board } \\
\text { performance. }\end{array}$ & & & & & & & & & & \\
\hline ii. $\begin{array}{l}\text { Obstruct Board } \\
\text { performance. }\end{array}$ & & & & & & & & & & \\
\hline iii. $\begin{array}{l}\text { Are irrelevant to } \\
\text { Board performance. }\end{array}$ & & & & & & & & & & \\
\hline
\end{tabular}

Please comment on your rating to statements 2.13 to 2.15 , explaining your viewpoint on each statement.

\section{Implications of Family Relations in Senior Positions}

2.16 What are your views with regards to family relationships between:

i. members of the Board and management;

ii. members of the Board themselves;

iii. the Chairman and the CEO?

iv. Family constitution and family institutions

\begin{tabular}{|c|c|c|c|c|c|c|c|c|c|c|}
\hline & \multicolumn{10}{|c|}{ Number of Interviewees $=18$} \\
\hline & \multicolumn{2}{|c|}{$\begin{array}{l}\text { Strongl } \\
\text { y } \\
\text { Disagre } \\
\text { e }\end{array}$} & \multicolumn{2}{|c|}{$\begin{array}{l}\text { Disagre } \\
\text { e }\end{array}$} & \multicolumn{2}{|c|}{$\begin{array}{l}\text { Neutr } \\
\text { al }\end{array}$} & \multicolumn{2}{|c|}{ Agree } & \multicolumn{2}{|c|}{$\begin{array}{l}\text { Strongly } \\
\text { Agree }\end{array}$} \\
\hline & G1 & $\begin{array}{l}\mathbf{G} \\
2\end{array}$ & $\begin{array}{l}G \\
1\end{array}$ & $\begin{array}{l}G \\
2\end{array}$ & $\begin{array}{l}G \\
1\end{array}$ & $\begin{array}{l}G \\
2\end{array}$ & $\begin{array}{l}G \\
1\end{array}$ & $\begin{array}{l}G \\
2\end{array}$ & G1 & G2 \\
\hline $\begin{array}{l}\text { 2.17 Developing a family } \\
\text { constitution is beneficial for } \\
\text { listed family businesses. }\end{array}$ & & & & & & & & & & \\
\hline
\end{tabular}

\begin{tabular}{|c|c|c|c|c|c|c|c|c|c|c|}
\hline \multirow{3}{*}{$\begin{array}{l}2.18 \text { Business operations } \\
\text { will be performed } \\
\text { more smoothly by } \\
\text { incorporating a: }\end{array}$} & \multicolumn{10}{|c|}{ Number of Interviewees $=18$} \\
\hline & \multicolumn{2}{|c|}{$\begin{array}{l}\text { Strongly } \\
\text { Disagree }\end{array}$} & \multicolumn{2}{|c|}{ Disagree } & \multicolumn{2}{|c|}{ Neutral } & \multicolumn{2}{|c|}{ Agree } & \multicolumn{2}{|c|}{$\begin{array}{l}\text { Strongly } \\
\text { Agree }\end{array}$} \\
\hline & G1 & G2 & G1 & G2 & G1 & G2 & G1 & G2 & G1 & G2 \\
\hline i. Family assembly. & & & & & & & & & & \\
\hline ii. Family council. & & & & & & & & & & \\
\hline
\end{tabular}


iii. Family office.

Please comment on your rating to statements 2.17 and 2.18, explaining your viewpoint on each statement.

Section 3: Maltese regulatory framework

\section{This section deals with the Maltese regulatory framework regarding corporate} governance in listed family businesses.

3.1 Does the Code of Principles of Good Corporate Governance for Listed Entities adequately fulfils the needs of Maltese listed family-controlled or influenced businesses as it does for their non-family counterparts?

\begin{tabular}{|c|c|c|c|c|c|c|c|c|c|c|c|}
\hline \multirow[t]{3}{*}{3.2} & \multirow{3}{*}{$\begin{array}{l}\text { The Code should } \\
\text { include recommendations } \\
\text { with respect } \\
\text { to the: }\end{array}$} & \multicolumn{10}{|c|}{ Number of Interviewees $=18$} \\
\hline & & \multicolumn{2}{|c|}{$\begin{array}{l}\text { Strongly } \\
\text { Disagree }\end{array}$} & \multicolumn{2}{|c|}{ Disagree } & \multicolumn{2}{|c|}{ Neutral } & \multicolumn{2}{|c|}{ Agree } & \multicolumn{2}{|c|}{$\begin{array}{l}\text { Strongly } \\
\text { Agree }\end{array}$} \\
\hline & & G1 & G2 & G1 & G2 & G1 & G2 & G1 & G2 & G1 & G2 \\
\hline i. & $\begin{array}{l}\text { The proportion of } \\
\text { family and non-family } \\
\text { directors serving on the } \\
\text { Board. }\end{array}$ & & & & & & & & & & \\
\hline ii. & $\begin{array}{l}\text { The proportion of } \\
\text { family members sitting } \\
\text { on the nomination } \\
\text { committee. }\end{array}$ & & & & & & & & & & \\
\hline iii. & $\begin{array}{l}\text { The proportion of } \\
\text { family members sitting } \\
\text { on the remuneration } \\
\text { committee. }\end{array}$ & & & & & & & & & & \\
\hline iv. & $\begin{array}{l}\text { Family } \\
\text { relationship between the } \\
\text { Chairman and the CEO. }\end{array}$ & & & & & & & & & & \\
\hline v. & $\begin{array}{l}\text { Periodic rotation } \\
\text { of family members } \\
\text { occupying executive } \\
\text { directorships. }\end{array}$ & & & & & & & & & & \\
\hline vi. & \begin{tabular}{l}
\multicolumn{1}{c}{ Formal } \\
establishment of a \\
family constitution.
\end{tabular} & & & & & & & & & & \\
\hline vii. & $\begin{array}{l}\text { Use of a family } \\
\text { assembly and family } \\
\text { council. }\end{array}$ & & & & & & & & & & \\
\hline viii. & $\begin{array}{l}\text { Preparation of the } \\
\text { agenda of Board } \\
\text { meetings. }\end{array}$ & & & & & & & & & & \\
\hline
\end{tabular}

3.3 What regulatory and/or other improvements would you suggest to enhance the corporate governance of listed family-controlled or influenced entities?

Any other comments? 